\title{
Flavonoids from Annona dioica Leaves and their Effects in Ehrlich Carcinoma Cells, DNA-topoisomerase I and II
}

\author{
Maria R. G. Vega, ${ }^{a}$ Andressa Esteves-Souza, ${ }^{a}$ Ivo J. C. Vieira, ${ }^{b}$ Leda Mathias, ${ }^{b}$ \\ Raimundo Braz-Filho ${ }^{b}$ and Aurea Echevarria ${ }^{*, a}$ \\ ${ }^{a}$ Departamento de Química, Universidade Federal Rural do Rio de Janeiro, \\ 23851-970 Seropédica-RJ, Brazil \\ ${ }^{b}$ Laboratório de Ciências Químicas, Centro de Ciência e Tecnologia, Universidade Estadual do \\ Norte Fluminense, 28013-602 Campos dos Goytacazes-RJ, Brazil
}

\begin{abstract}
A investigação fitoquímica do extrato metanólico das folhas de Annona dioica (Annonaceae) resultou na identificação dos flavonóides kaempferol (1), 3-O-[3",6"-di-O-p-hidroxicinamoil]$\beta$-galactopiranosil-kaempferol (2), 6"-O-p-hidroxicinamoil- $\beta$-galactopiranosil-kaempferol (3) e 3-O- $\beta$-galactopiranosil-kaempferol (4). As estruturas foram caracterizadas inequivocamente através de análises espectroscópicas utilizando-se RMN de ${ }^{1} \mathrm{H}$ e ${ }^{13} \mathrm{C}$ uni e bi-dimensional. Os efeitos citotóxicos dos flavonóides e da fração flavonoídica (FF) foram avaliados frente a células do carcinoma de Ehrlich, utilizando-se o ensaio do MTT (brometo de 3-(4,5dimetiltiazol-2-il)-2,5-difeniltetrazolium). Os resultados indicaram que 1, 2, 3 e FF apresentam ação anti-proliferativa importante quando comparados com a quercetina. A ação inibitória dos flavonóides sobre as DNA-topoisomerases I e II foi avaliada utilizando-se o ensaio de relaxação sobre o plasmídeo pBR322. Os resultados indicaram ação não seletiva dos flavonóides sobre as DNA-topoisomerases I e II.
\end{abstract}

Chemical investigation of methanol extract leaves from Annona dioica (Annonaceae) resulted in the identification of flavonoids kaempferol (1), 3-O-[3",6"-di-O-p-hydroxycinnamoyl]- $\beta$ galactopyranosyl-kaempferol (2), 6"-O-p-hydroxycinnamoyl- $\beta$-galactopyranosyl-kaempferol (3) and 3-O- $\beta$-galactopyranosyl-kaempferol (4). The structures were unequivocally characterized by ${ }^{1} \mathrm{H}$ and ${ }^{13} \mathrm{C}$ NMR spectroscopic analyses using $1 \mathrm{D}$ and $2 \mathrm{D}$ experiments. The cytotoxic effects of the flavonoids and flavonoid fraction (FF) were evaluated by MTT (3-(4,5-dimethylthiazol-2yl)-2,5-diphenyltetrazolium bromide) assay against Ehrlich carcinoma cells. The results indicated that 1, 2, 3 and FF exhibit significant antiproliferative action when compared to quercetin. The inhibitory action on DNA-topoisomerase I and II of all the flavonoids was evaluated by relaxation assays on pBR322 plasmid DNA. The results indicated the inhibitory and non-selective effects of the flavonoids on DNA-topoisomerase I and II.

Keywords: Annona dioica, Annonaceae, cytotoxic activity, flavonoids, DNA-topoisomerase

\section{Introduction}

The Annonaceae represents a large pan tropical family comprising approximately 120 genera and 2,000-2,200 species. The family is extremely important since it is the source of several edible fruits; seeds of some plants may be used for the production of edible oils; wood from some annonaceous plants has been employed in alcohol production, and the fragrant flowers of Cananga odorata are an important raw material for perfumery. ${ }^{1}$ Further,

*e-mail: echevarr@ufrrj.br many members of this family are used in folk medicine for different purposes. ${ }^{2}$

Chemical studies, and to a lesser extent pharmacological investigations, on Annonaceae plants involved the search of alkaloids in the past, and of the acetogenins in the last decade. However, amino acids, carbohydrates, lipids, proteins, polyphenols, essential oils, terpenes and aromatic compounds are also typically found in these plants.

Flavonoids, a heterogeneous group of ubiquitous plant polyphenols, are a frequent component of the human diet. ${ }^{3}$ A large number of biological activities has been attributed 
to these compounds, including anticancer activity. ${ }^{4-6}$ The flavonoid compounds on the diet may act as chemopreventive agents against the development of cancer in the alimentary tract. ${ }^{7}$ In fact, a number of studies has demonstrated anticancer activity associated with flavonoids. ${ }^{8}$ These compounds are constituents of herbal treatments used by lay practitioners for a long time, but their effects as individual compound have only recently been recognized. ${ }^{9}$

DNA supercoiling is a precisely regulated process that influences DNA replication, transcription and packaging. DNA topoisomerases are enzymes that modulate the topological state of DNA. The interest in these enzymes has increased in the last few decades; and they have been shown to be the target enzymes for many effective drugs in cancer treatment. ${ }^{10}$

As part of our continuing search for potential anticancer drug candidates from South American medicinal plants, we decided to study Annona dioica, Annonaceae, with its very appreciable fruits, a shrub which is widely dispersed in South America, extending from Bolivia to Paraguay. In Brazil, the fruits and leaves are used against rheumatism and the seeds against diarrhea, ${ }^{11}$ and in Paraguay the leaves are used to make tea or to gargle as an anti-catarrhal, while the edible fruits possess sedative properties and their seeds are used as insecticides or in the treatment of parasitic infections of the skin. ${ }^{12}$

Previous phytochemical investigations of the Annona dioica ethanolic extract of Annona dioica, collected in Serra da Moeda (Minas Gerais state of Brazil), led to the isolation and characterization of six alkaloids. ${ }^{13} \mathrm{~A}$ taxonomic study of the Brazilian Annonaceae foliar material also indicated the presence of flavonoids. ${ }^{14}$

In this paper we report for the first time the isolation and characterization of the four foliar flavonoids, kaempferol (1), 3-O-[3",6"-di-O-p-hydroxycinnamoyl]$\beta$-galactopyranosyl-kaempferol (2), 6"-O-p-hydroxycinnamoyl- $\beta$-galactopyranosyl-kaempferol (3) and 3-O$\beta$-galactopyranosyl-kaempferol (4), from a methanolic extract of the leaves of Annona dioica colleted in Paraguay (see Figure 1). These flavonoids 1-4 were characterized by spectroscopic analyses involving IR, ${ }^{1} \mathrm{H}$ (1D and $\left.2 \mathrm{D}{ }^{1} \mathrm{H}-{ }^{1} \mathrm{H}-\mathrm{COSY}\right),{ }^{13} \mathrm{C}\left(\left\{{ }^{1} \mathrm{H}\right\}-\right.$ and APT), HMQC and HMBC NMR spectra and comparison to the previous literature data. In addition, these flavonoids (1-4) and the methanol fraction FF were evaluated for cytotoxic activities against Ehrlich carcinoma cells and DNA topoisomerase I and II- $\alpha$ inhibitory activities.

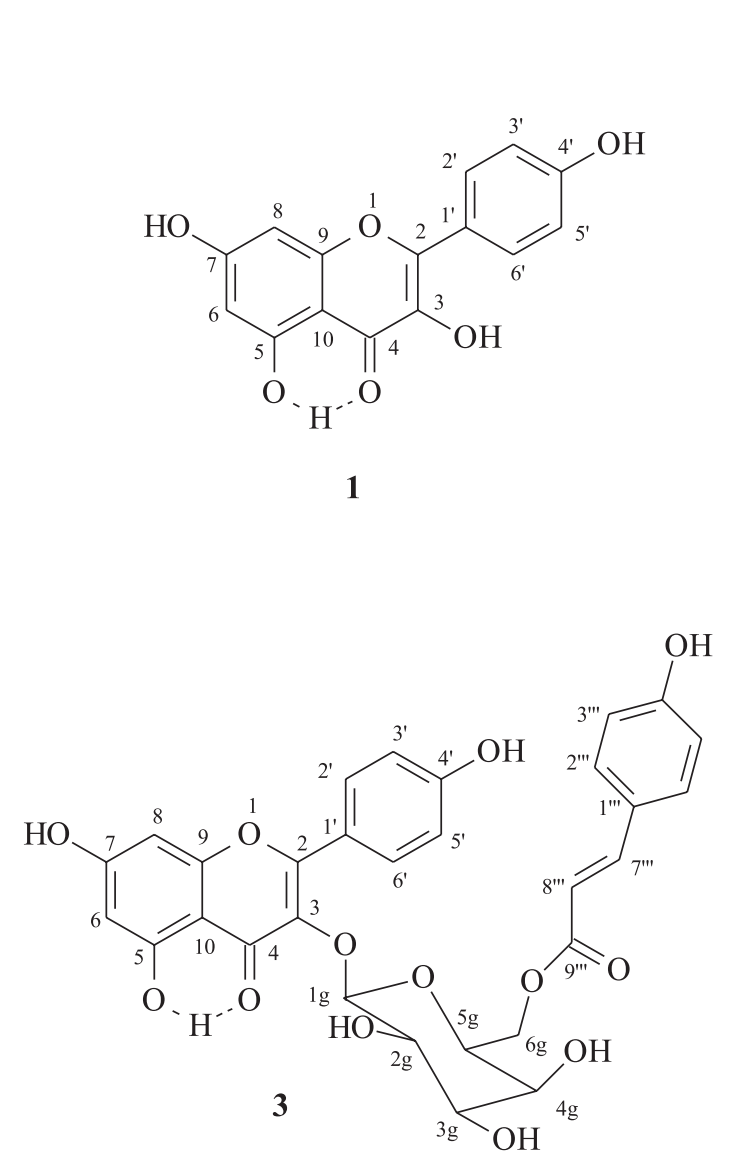

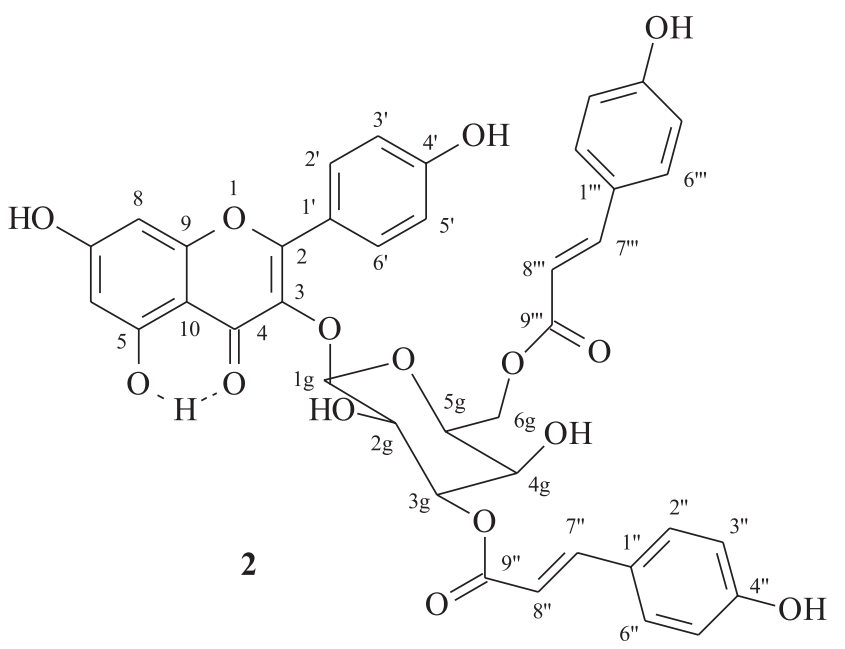

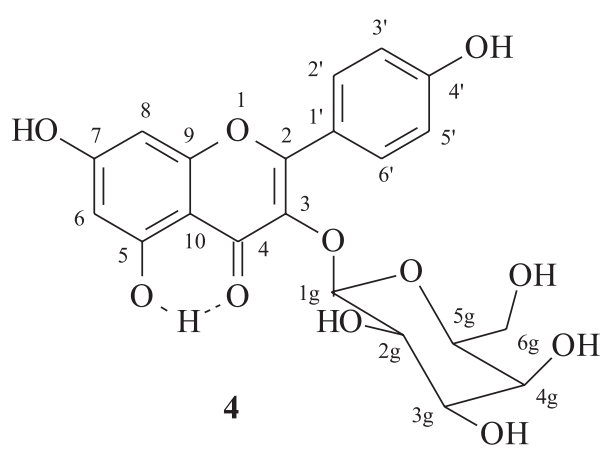

Figure 1. Flavonoids isolated from Annona dioica leaves methanol extract. 


\section{Experimental}

\section{General}

${ }^{1} \mathrm{H}-\mathrm{NMR}$ and ${ }^{13} \mathrm{C}-\mathrm{NMR}$ spectra were recorded on a JEOL Eclipse (400 MHz and $100 \mathrm{MHz}$, respectively) spectrometer. Chemical shifts are given in $\delta$ units, relative to the tetramethylsilane (TMS) signal as an internal standard.

\section{Plant material}

Leaves of $A$. dioica were collected in Cerrado of Horqueta, Paraguay, in February of 1999. The voucher specimen (No. 8567) was deposited in the Departamento de Botanica of Universidad Nacional, Asunción, Paraguay.

\section{Extraction and isolation}

The leaves were extracted by maceration with hexane and methanol. The methanol extract (120.2 g) was partitioned between $\mathrm{CH}_{2} \mathrm{Cl}_{2}$ and $\mathrm{MeOH}: \mathrm{H}_{2} \mathrm{O}(2: 1)$ to furnish hydroalcoholic and dichloromethane fractions. A portion of the methanolic fraction was separated for biological assays (FF) and the rest of the material, $50.7 \mathrm{~g}$, was chromatographed on a silica gel column using a polarity gradient of $\mathrm{CHCl}_{3}$ /acetone/ $\mathrm{MeOH}$ as eluents to yield 36 fractions. The 1-10 fractions $(0.25 \mathrm{~g})$ furnished a sitosterol and stigmasterol mixture, after elution with hexane: $\mathrm{CH}_{2} \mathrm{Cl}_{2}(8: 2)$ as solvent system. The fraction $12(0.075 \mathrm{~g})$ was purified by preparative TLC using $\mathrm{CH}_{2} \mathrm{Cl}_{2}$ :acetone (1:1) as solvent system, and furnished the flavonoid 2 (0.015 g, CAS number 606138-07-2, $\mathrm{C}_{39} \mathrm{H}_{32} \mathrm{O}_{15}, \mathrm{MW}$ 740, mp 181-183 $\left.{ }^{\circ} \mathrm{C}\right)$. The fractions $13-15(0.14 \mathrm{~g})$ were chromatographed on a Sephadex LH-20 column using $\mathrm{MeOH}$ as solvent affording the flavonoids $\mathbf{1}$ (0.018 g, CAS number 520-18-3, $\mathrm{C}_{15} \mathrm{H}_{10} \mathrm{O}_{6}$, MW 286, $\left.\mathrm{mp} 285-286{ }^{\circ} \mathrm{C}\right), 3$ (0.024 g, CAS number 68170-52$\left.2, \mathrm{C}_{30} \mathrm{H}_{26} \mathrm{O}_{13}, \mathrm{MW} 594, \mathrm{mp} 269-271^{\circ} \mathrm{C}\right)$ and $4(0.004$ g, CAS number 23627-87-4, $\mathrm{C}_{21} \mathrm{H}_{20} \mathrm{O}_{11}, \mathrm{MW} 448, \mathrm{mp}$ 230-232 ${ }^{\circ} \mathrm{C}$ ).

\section{Bioassays}

\section{Cell culture}

Ehrlich carcinoma cells were maintained for 12-14 days in Swiss mice. The tumor cell cultures were started from mouse Ehrlich ascites with at least one passage in vitro prior to use.
Cytotoxicity assay

Aliquots of $5 \times 10^{5}$ tumor cells were seeded onto 96 well flat microplates in RPMI 1640 complete medium. The flavonoids 1-4 and quercetin (positive control) in $0.5 \%$ (v/ v) DMSO:saline at final concentrations of 50, 25, 12.5 and $6.25 \mu \mathrm{mol} \mathrm{L}{ }^{-1}$, and FF at concentration of 30, 15, 7.5 and $3.75 \mathrm{ng} \mathrm{mL}^{-1}$ were added to cells and incubated at $37^{\circ} \mathrm{C}$ in the presence of $5 \% \mathrm{CO}_{2}$. The same volume was used as negative control. After $48 \mathrm{~h}$ of cell culture, MTT (3-(4,5dimethylthiazol-2-yl)-2,5-diphenyltetrazolium bromide) was added to the samples and the absorbance was read at $570 \mathrm{~nm}$ after $3 \mathrm{~h}$ at $37^{\circ} \mathrm{C} .{ }^{15} \mathrm{The}^{\mathrm{IC}} \mathrm{C}_{50}$ values were reported as means $\pm \mathrm{SD}$ of three independent experiments. Statistical significance was assessed by the Student's $t$-test.

\section{DNA-topoisomerase I assay}

The topo I inhibition was determined by relaxation assay and was carried out as described in the TopoGEN screening kit. Briefly, $0.125 \mu \mathrm{g}$ of the supercoiled pBR322 plasmid DNA (Invitrogen) was incubated with one unit of the enzyme in the presence or absence of flavonoids for $30 \mathrm{~min}$ at $37^{\circ} \mathrm{C}$, in reaction buffer. Reaction products were loaded onto a $1 \%$ agarose gel containing ethidium bromide. Electrophoresis was carried out in tris-acetateEDTA pH 8.5 at $15 \mathrm{~V}$ for $3.5 \mathrm{~h}$ and then photographed with a digital camera by illumination.

\section{DNA-topoisomerase II assay}

The topo II- $\alpha$ inhibition was carried out as described in the TopoGEN screening kit. Briefly, the reaction mixture containing the flavonoid, $0.125 \mu \mathrm{g} \mathrm{mL}^{-1} p \mathrm{BR} 322$ (Invitrogen), assay buffer, $2 \mathrm{U}$ of topo II- $\alpha$, and water was incubated at $37{ }^{\circ} \mathrm{C}$ for $30 \mathrm{~min}$. The reaction products were submitted to electrophoresis using $1 \%$ agarose gel in $1 \times$ TAE buffer $(50 \times$ stock: $242 \mathrm{~g}$ Tris base, $57.1 \mathrm{~mL}$ glacial acetic acid and 100 $\mathrm{mL}$ of $0.5 \mathrm{~mol} \mathrm{~L}^{-1}$ EDTA) at $15 \mathrm{~V}$ for $3.5 \mathrm{~h}$. Gels were stained with ethidium bromide $\left(0.5 \mu \mathrm{g} \mathrm{mL}^{-1}\right)$ for $30-45 \mathrm{~min}$, washed and photographed under UV light.

\section{Results and Discussion}

The flavonoids were isolated from methanol and hexane extracts of Annona dioica as indicated in Experimental section. The ${ }^{1} \mathrm{H}$ NMR of flavonoids 1-4 showed typical signals of substitution for the standard kaempferol flavonoid. The A ring of flavonoid 1 showed two doublets $(J 2.1 \mathrm{~Hz}$, meta-coupling) at $\delta_{\mathrm{H}} 6.2$ and 6.4 attributed to hydrogen atoms $\mathrm{H}-6$ and $\mathrm{H}-8$, respectively.

Analogously, the ${ }^{1} \mathrm{H}$ NMR spectra of the flavonoids 2-4 showed the same substitution pattern for the A ring of 1, with signals for H-6 at $\delta_{\mathrm{H}} 6.3(J 2.2 \mathrm{~Hz}, 2), 6.1(J 1.9$ 
$\mathrm{Hz}, 3)$ and $6.0(J 2.2 \mathrm{~Hz}, 4)$, and for H-8 at $\mathrm{d}_{\mathrm{H}} 6.5(J 2.2$ $\mathrm{Hz}, 2), 6.3(J 1.9 \mathrm{~Hz}, 3)$ and $6.2(J 2.2 \mathrm{~Hz}, 4)$. Singlet signal at $\delta_{\mathrm{H}} 12.37$ was attributed to the hydroxyl group at carbon atom C-5 (HO-5, quelatogenic hydroxyl function). This 5,7-dihydroxy substitution pattern in the four flavonoids was confirmed by ${ }^{13} \mathrm{C}$ chemical shifts of the methine carbon atoms CH-6 [ $\delta_{\mathrm{C}} 99.3$ (1), 99.9 (2), 100.1 (3) and 99.7 (4)], CH-8 [ $\delta_{\mathrm{C}} 94.5$ (1), 94.8 (2), 94.8 (3) and 94.5 (4)], and by the signals corresponding to quaternary carbons C-5, C-7, C-9 and C-10 (Table 1).

The presence of AA'BB' system in the B ring (4'hydroxylated) of the four flavonoids was revealed by ${ }^{1} \mathrm{H}$ NMR spectra through doublet $(J 8.8$ to $8.9 \mathrm{~Hz}$, orthocoupling) signals corresponding to $\mathrm{H}-2^{\prime} / \mathrm{H}-6$ ' at $\delta_{\mathrm{H}} 8.1$ (1), $8.2(2), 8.1(3)$ and $8.1(\mathbf{4})$, and $\mathrm{H}-3^{\prime} / \mathrm{H}-5^{\prime}$ ' at $\delta_{\mathrm{H}} 6.9(\mathbf{1}), 7.0$ (2), 6.8 (3) and 6.9 (4). The HMQC spectra showed crosspeaks indicating direct 2D-shift-correlations of these hydrogen signals with the corresponding ${ }^{13} \mathrm{C}$ signals (Table 1) of the methine carbons $\mathrm{CH}-2^{\prime} / \mathrm{CH} 6$ ' $\left(\delta_{\mathrm{C}} 130.7\right.$ to 132.3$)$ and $\mathrm{CH}-3^{\prime} / \mathrm{CH}-5$ ' $\left(\delta_{\mathrm{C}} 115.9\right.$ to 116.3$)$.

Comparative analysis of the ${ }^{1} \mathrm{H}\left(1 \mathrm{D}\right.$ and $2 \mathrm{D}{ }^{1} \mathrm{H}-{ }^{1} \mathrm{H}-$ $\mathrm{COSY})$ and ${ }^{13} \mathrm{C}\left(\left\{{ }^{1} \mathrm{H}\right\}\right.$ and $\left.\mathrm{APT}\right) \mathrm{NMR}$ spectra of $\mathbf{1}$ and $\mathbf{2 - 4}$ revealed the additional presence of signals which allowed the identification of the unsubstituted galactopyranosyl moiety (4), 3,6-di- $O$ - $p$-hydroxycinnamoyl-(2) and 3-O-phydroxycinnamoyl-(3), represented by the doublet $(J 8.0$ to $7.5 \mathrm{~Hz}$, axial-axial couplings) signals corresponding to anomeric hydrogens $\mathrm{H}-1 \mathrm{~g}$ at $\delta_{\mathrm{H}} 5.4$ (2), 5.1 (3), and 5.0 (4), which were confirmed by the HMQC heteronuclear correlations with the ${ }^{13} \mathrm{C}$ signals at $\mathrm{d}_{\mathrm{C}} 105.5,105.0$ and 103.0, respectively (Table 1). This galactopyranosyl unit was located in the carbon C-3 (3-O-galactopyranosyl) based on the deshielding effect (e.g. $\Delta \delta_{\mathrm{C}}=158.7$ (2) - $148.1(\mathbf{1})=10.7 \mathrm{ppm})$ observed in the chemical shifts (Table 1) of the carbon atom $\mathrm{C}-2$ of $\mathbf{2}\left(\delta_{\mathrm{C}}\right.$ 158.7), 3 $\left(\delta_{\mathrm{C}} 159.1\right)$ and $4\left(\delta_{\mathrm{C}} 157.9\right)$ when compared to C-2 of $\mathbf{1}$ $\left(\delta_{\mathrm{C}} 148.1\right){ }^{16}$

The ${ }^{1} \mathrm{H}$ and ${ }^{13} \mathrm{C}$ NMR spectra of flavonoid $\mathbf{2}$ and $\mathbf{3}$ (Table 1) showed additional signals attributed to one (3) and two $p$-hydroxycinnamoyl (2) units. The location of these $p$ hydroxycinnamoyl moieties at methylene group $\mathrm{CH}_{2}-6 \mathrm{~g}$ of $\mathbf{2}\left(\delta_{\mathrm{C}} 65.6\right)$ and $\mathbf{3}\left(\delta_{\mathrm{C}} 64.4\right)$ was established by conspicuous deshielding $\left(\Delta \delta_{\mathrm{C}}=3.5(2)\right.$ and $\left.2.3(\mathbf{3}) \mathrm{ppm}\right)$ of $2\left(\delta_{\mathrm{C}} 65.6\right)$ and $3\left(\delta_{\mathrm{C}} 64.4\right)$, observed when compared to the chemical shift of these group in $4\left(\delta_{\mathrm{C}} 62.1\right)$. This was confirmed by the shielding ( $\gamma$-effect) shown by the chemical shifts of the carbon atoms $\mathrm{CH}-5 \mathrm{~g}\left[\Delta \delta_{\mathrm{C}}=74.1\right.$ (2) - 78.3 (4) $=-4.2$ and $74.8(3)-78.3(4)=-3.5 \mathrm{ppm}]$. The analogous $\gamma$-effects were observed in the carbon atoms $\mathrm{CH}-2 \mathrm{~g}$ and $\mathrm{CH}-4 \mathrm{~g}$ of $\mathbf{2}$, justifying the presence of an additional $p$-hydroxycinnamoyl at carbon $\mathrm{CH}-3 \mathrm{~g}$ (Table 1).

The presence of cinnamoyl units was recognized by ${ }^{1} \mathrm{H}\left(1 \mathrm{D}\right.$ and $\left.2 \mathrm{D}{ }^{1} \mathrm{H}-{ }^{1} \mathrm{H}-\mathrm{COSY}\right)$ and ${ }^{13} \mathrm{C}$ (Table 1) NMR spectra. The doublet $(J 8.4 \mathrm{~Hz})$ signals corresponding to $\mathrm{H}-2$ " $/ \mathrm{H}-6$ " at $\delta_{\mathrm{H}} 7.6$ and $\mathrm{H}-3 " / \mathrm{H}-5$ " at $\delta_{\mathrm{H}} 6.9$, as well as $\mathrm{H}-2$ "'/H-6" at $\delta_{\mathrm{H}} 7.4$ and H-3"'/H-5" at $\delta_{\mathrm{H}} 6.9$. The trans (E) stereochemistries were deduced by coupling constants for H-7"/ H-8" $\delta_{\mathrm{H}} 7.7$ and 6.3, respectively $(J 15.8 \mathrm{~Hz}, 2)$, $\delta_{\mathrm{H}} 7.5$ and 6.2 for H-7"'/ H-8"' $(J 16.1 \mathrm{~Hz}, 2)$, and for 3, signals corresponding to two doublets at $\delta_{\mathrm{H}} 7.4$ and $6.0(\mathrm{~J}$ $15.8 \mathrm{~Hz}, 3$ ) were observed. The complete ${ }^{1} \mathrm{H}$ and ${ }^{13} \mathrm{C}$ chemical shift assignments of these flavonoids were also based on the homonuclear $2 \mathrm{D}{ }^{1} \mathrm{H}-{ }^{1} \mathrm{H}-\mathrm{COSY}$ and heteronuclear $2 \mathrm{D}{ }^{1} \mathrm{H}-{ }^{13} \mathrm{C}$ shift-correlated (HMQC and $\mathrm{HMBC}$ ) experiments and compared to previous incomplete literature data. ${ }^{16-19}$

Table 1. ${ }^{13} \mathrm{C}(100 \mathrm{MHz})$ NMR data for flavonoids 1-4 from $A$ dioica in $\mathrm{MeOH}-d_{4}(\mathbf{1}, \mathbf{3}$ and $\mathbf{4})$ and acetone- $d_{6}(\mathbf{2})$ as solvent. Chemical shifts in $\delta_{\mathrm{C}}{ }^{*}$

\begin{tabular}{|c|c|c|c|c|c|c|c|c|c|}
\hline $\mathrm{C}$ & 1 & 2 & 3 & 4 & $\mathrm{C}$ & 1 & 2 & 3 & 4 \\
\hline 2 & 148.1 & 158.7 & 159.1 & 157.9 & $2^{\prime}, 6^{\prime}$ & 130.7 & 132.3 & 132.2 & 132.1 \\
\hline 3 & 137.1 & 135.5 & 135.5 & 131.2 & $3^{\prime}, 5^{\prime}$ & 116.3 & 115.9 & 116.0 & 116.3 \\
\hline 4 & 178.0 & 179.1 & 179.7 & 178.4 & $2^{\prime \prime}, 6^{\prime \prime}$ & - & 131.0 & - & - \\
\hline 5 & 160.6 & 162.9 & 161.6 & 162.1 & $3^{\prime \prime}, 5^{\prime \prime}$ & - & 116.7 & - & - \\
\hline 7 & 165.7 & 165.4 & 166.1 & 162.5 & $7^{\prime \prime}$ & - & 145.6 & - & - \\
\hline 9 & 158.3 & 158.0 & 158.4 & 157.9 & $8^{\prime \prime}$ & - & 115.8 & - & - \\
\hline 10 & 104.5 & 105.4 & 105.5 & 105.2 & $2^{\prime \prime \prime}, 6^{\prime \prime \prime}$ & - & 131.0 & 131.1 & - \\
\hline $1^{\prime}$ & 123.8 & 122.4 & 122.6 & 122.7 & $3^{\prime \prime \prime}, 5^{\prime \prime \prime}$ & - & 116.7 & 116.7 & - \\
\hline $4^{\prime}$ & 162.5 & 161.1 & 161.2 & 159.9 & $7^{\prime \prime \prime}$ & - & 145.6 & 146.6 & - \\
\hline $1^{\prime \prime}$ & - & 127.1 & - & - & $8^{\prime \prime \prime}$ & - & 115.1 & 114.7 & - \\
\hline $4^{\prime \prime}$ & - & 160.7 & - & - & Sugar & & & & \\
\hline $9^{\prime \prime}$ & - & 167.1 & - & - & $1 \mathrm{~g}$ & - & 105.5 & 105.0 & 103.0 \\
\hline $1^{\prime \prime \prime}$ & - & 126.9 & 127.1 & - & $2 \mathrm{~g}$ & - & 70.0 & 72.9 & 75.7 \\
\hline $4^{\prime \prime \prime}$ & - & 160.6 & 161.2 & - & $3 g$ & - & 76.9 & 74.9 & 78.2 \\
\hline $9^{\prime \prime \prime}$ & - & 167.1 & 168.7 & - & $4 \mathrm{~g}$ & - & 67.5 & 70.6 & 71.3 \\
\hline $\mathrm{CH}$ & & & & & $5 \mathrm{~g}$ & - & 74.1 & 74.8 & 78.3 \\
\hline 6 & 99.3 & 99.9 & 100.1 & 99.7 & $6 \mathrm{~g}$ & - & 65.6 & 64.4 & 62.1 \\
\hline 8 & 94.5 & 94.8 & 94.8 & 94.5 & & & & & \\
\hline
\end{tabular}

*Carbon signals corresponding to $\mathrm{C}, \mathrm{CH}$ and $\mathrm{CH}_{2}$ deduced by comparative analysis of $\{1 \mathrm{H}\}$ and $\mathrm{APT}{ }^{13} \mathrm{C}$ NMR spectra. Heteronuclear $2 \mathrm{D} \mathrm{HMQC}$ and $\mathrm{HMBC}$ spectra were also used for these assignments. 
The cytotoxic activities of the flavonoids (1-4) and the methanolic fraction $(\mathbf{F F})$ were assayed in vitro against murine Ehrlich carcinoma $\left(1 \times 10^{5}\right.$ cells $)$. Cell viability was assayed in the presence or absence of 1-4, FF and quercetin, utilized as a positive control, using the Mossman assay. ${ }^{15}$ The flavonoids 1-3 and FF exhibited concentrationdependent growth inhibiting activities against cultured Ehrlich carcinoma cells (see Figure 2). The $\mathrm{IC}_{50}$ values were $(7.8 \pm 0.1),(10.9 \pm 0.5)$ and $(14.7 \pm 1.4) \mathrm{mmol} \mathrm{mL}^{-1}$ for $\mathbf{1}, \mathbf{2}$ and $\mathbf{3}$, respectively. The flavonoid $\mathbf{4}$ did not show significant cytotoxicity until the dose of $50 \mu \mathrm{mol} \mathrm{L}^{-1}$, while the methanolic fraction FF showed the best activity with an $\mathrm{IC}_{50}$ value of $4.0 \pm 0.1 \mathrm{ng} \mathrm{mL}^{-1}$, suggesting a probable synergistic effect of flavonoids $\mathbf{1 - 3}$ (Table 2). The comparison of the $\mathrm{IC}_{50}$ values between the flavonols quercetin $\left(\mathrm{IC}_{50}=44.0 \pm 4.0\right) \mu \mathrm{mol} \mathrm{L}-1$ and kaempferol (1, $\left.\mathrm{IC}_{50}=7.8 \pm 0.1 \mu \mathrm{mol} \mathrm{L}-1\right)$ showed the importance of the hydroxylation pattern of the $\mathrm{B}$ ring. The absence of the $p$ hydroxycinnamoyl moiety linked to galactopyranosyl group located in the carbon C-3 of kaempferol led to the inactivity of $\mathbf{4}$.

The conversion of supercoiled plasmid DNA to relaxed DNA by human topoisomerases I and II- $\alpha$ was examined

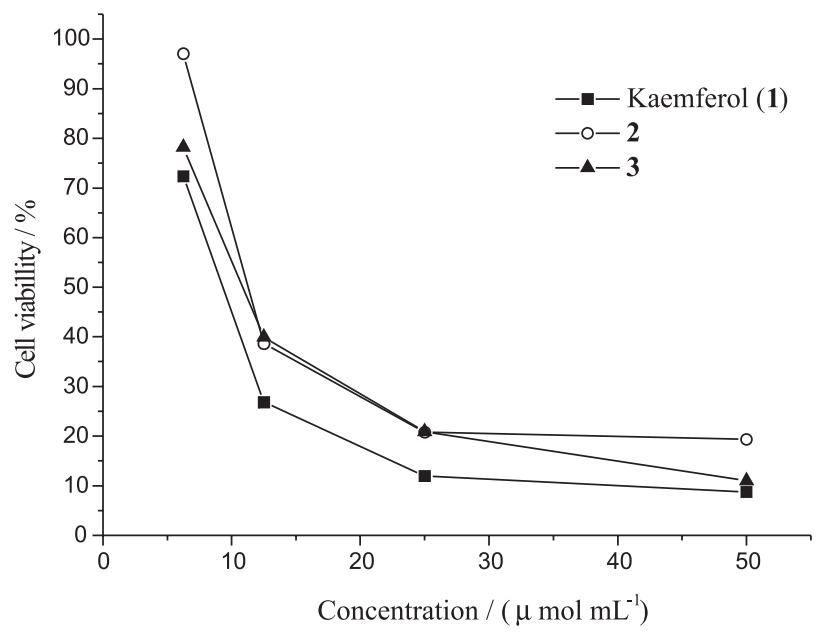

Figure 2. Dose-dependent antiproliferative effect of flavonoids 1, 2 and $\mathbf{3}$ against cultured Ehrlich carcinoma cells.

Table 2. $\mathrm{IC}_{50}\left(\mathrm{mmol} \mathrm{mL}^{-1}\right.$ and $\left.\mathrm{ng} \mathrm{mL} \mathrm{mL}^{-1}\right)$ values of the flavonoids 1-4 and fraction $\mathbf{F F}$ against Ehrlich carcinoma cells

\begin{tabular}{lcc}
\hline Natural products & \multicolumn{2}{c}{$\mathrm{IC}_{50}\left( \pm \mathrm{sd}^{\mathrm{a}}\right)$} \\
\cline { 2 - 3 } & $\mathrm{mmol} \mathrm{mL}^{-1}$ & $\mathrm{ng} \mathrm{mL}^{-1}$ \\
\hline Quercetin & $44.0 \pm 4.0$ & $13.29 \pm 1.3$ \\
$\mathbf{1}$ & $7.8 \pm 0.1$ & $22.2 \pm 2.2$ \\
$\mathbf{2}$ & $10.9 \pm 0.5$ & $80.7 \pm 4.0$ \\
$\mathbf{3}$ & $14.7 \pm 1.4$ & $87.4 \pm 8.7$ \\
$\mathbf{4}$ & $\mathrm{na}^{\mathrm{b}}$ & $\mathrm{na}$ \\
$\mathbf{F F}$ & - & $4.0 \pm 0.1$ \\
\hline
\end{tabular}

${ }^{\mathrm{a}} \mathrm{Sd}$ : standard deviation; ${ }^{\mathrm{b} n a:}$ no activity until $50 \mathrm{mmol} \mathrm{mL} \mathrm{L}^{-1}$. in the presence of flavonoids (1-4) and FF. The activity of the flavonoids on DNA-topoisomerase was observed through relaxation assays of supercoiled $p$ BR322 plasmid DNA. Quercetin, a well-known topoisomerase I enzyme inhibitor, was used as a positive control. ${ }^{20}$ The results were observed by the alteration of $p \mathrm{BR} 322$ electrophoretic mobility by the combined action of topoisomerase I and flavonoids. The analysis of the results was performed by ethidium bromide addition under UV light, and the results were photographed with a digital camera. As shown in Figure 3 all the tested flavonoids (with the exception of FF) indicated inhibitory relaxation effects, with $\mathbf{2}$ being the most effective. This observation was based on the direct measurement of fluorescence intensity of the respective gel areas by video-enhanced imaging (line 5).

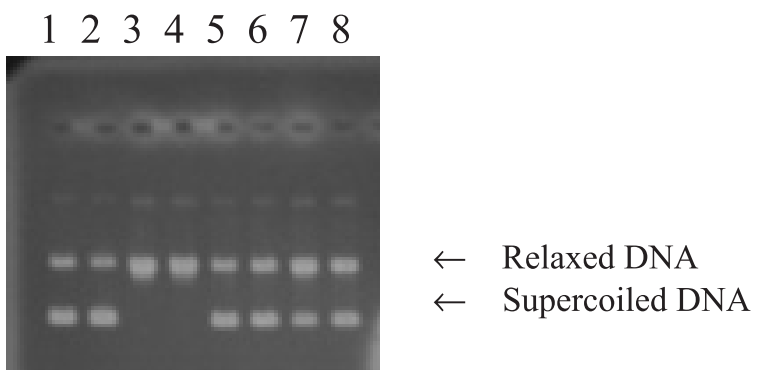

Figure 3. Effect of flavonoids on DNA-topoisomerase I. Line 1: topo I $(1 \mathrm{U})+$ pBR322 $(0.250 \mu \mathrm{g})+$ quercetin, $200 \mu \mathrm{mol} \mathrm{mL}^{-1}$; line 2: pBR322 $(0.250 \mu \mathrm{g})$ only; line $3: \mathrm{pBR} 322(0.250 \mu \mathrm{g})+$ topo I $(1 \mathrm{U})$; line 4 : topo I $(1 \mathrm{U})+$ pBR322 $(0.250 \mu \mathrm{g})+\mathbf{F F}, 20 \mu \mathrm{g} \mathrm{mL} \mathrm{m}^{-1}$; line 5: topo I $(1 \mathrm{U})+\mathrm{pBR} 322$ $(0.250 \mu \mathrm{g})+2,20 \mu \mathrm{mol} \mathrm{mL}^{-1}$; line 6: topo I $(1 \mathrm{U})+$ pBR322 $(0.250 \mu \mathrm{g})+$ 3, $20 \mu \mathrm{mol} \mathrm{mL}{ }^{-1}$; line 7: topo I $(1 \mathrm{U})+$ pBR322 $(0.250 \mu \mathrm{g})+\mathbf{4}, 20 \mu \mathrm{mol}$ $\mathrm{mL}^{-1}$; line 8: topo I $(1 \mathrm{U})+$ pBR322 $(0.250 \mu \mathrm{g})+\mathbf{1}, 20 \mu \mathrm{mol} \mathrm{mL}^{-1}$.

The inhibitory effects on DNA-topoisomerase II- $\alpha$ were also evaluated, by the relaxation assays using supercoiled $p$ BR322 plasmid DNA in the presence of ATP. Figure 4 showed that all assayed flavonoids, with exception of $\mathbf{4}$ which was not active, but including the FF fraction,

\section{$\begin{array}{lllllll}1 & 2 & 3 & 4 & 5 & 6 & 7\end{array}$}

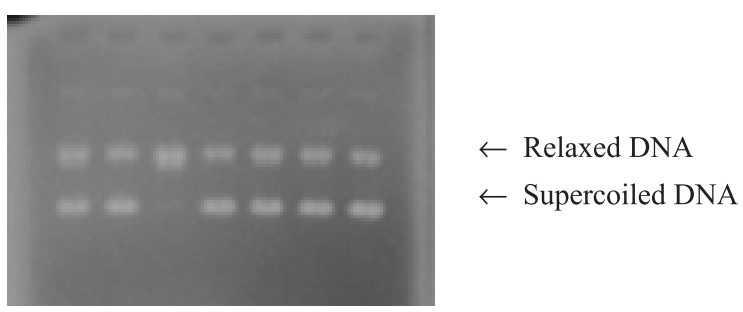

Figure 4. Effect of flavonoids on DNA-topoisomerase II-a. Line 1: topo II$\mathrm{a}(1 \mathrm{U})+\mathrm{pBR} 322(0.250 \mu \mathrm{g})+$ etoposide, $20 \mu \mathrm{mol} \mathrm{mL}^{-1}$; line $2: \mathrm{pBR} 322$ $(0.250 \mu \mathrm{g})$ only; line 3: pBR322 $(0.250 \mu \mathrm{g})+$ topo II-a (1U); line 4: topo II-a $(1 \mathrm{U})+$ pBR322 $(0.250 \mu \mathrm{g})+\mathbf{F F}, 20 \mu \mathrm{g} \mathrm{mL}-1$; line 5: topo II-a (1U) + pBR322 $(0.250 \mu \mathrm{g})+2,20 \mu \mathrm{mol} \mathrm{mL}^{-1}$; line 6: topo II-a $+(1 \mathrm{U})+$ pBR322 $(0.250 \mu \mathrm{g})+\mathbf{3}, 20 \mu \mathrm{mol} \mathrm{mL}-1$; line 7 : topo II-a $(1 \mathrm{U})+$ pBR322 $(0.250 \mu \mathrm{g})$ $+1,20 \mu \mathrm{mol} \mathrm{mL}{ }^{-1}$. 
demonstrated inhibitory effects on human DNAtopoisomerase II- $\alpha$ similar to the pattern observed for etoposide, line 1, which was used as positive control.

The analysis of DNA topoisomerase inhibition and Ehrlich cells antiproliferative activity results, in which FF shows potent cytotoxic activity and only inhibits DNAtopoisomerase II, suggests the major importance of DNA topoisomerase II inhibition in determining the level of cytotoxic activity, and confirms the synergistic effect of the flavonoids $\mathbf{1 - 3}$ in this fraction.

\section{Conclusions}

The occurrence of flavonoids 1-4 in the genus Annona is described here for the first time, and as reported in this work, they act on human topoisomerases I and II- $\alpha$ inhibiting the DNA relaxation effect including the non-cytotoxic compound $\mathbf{4}$, reinforcing the potential importance of their presence in the human diet.

\section{Supplementary Information}

Supplementary data of flavonoid structures as 1 and $2 \mathrm{D}{ }^{1} \mathrm{H}$ and ${ }^{13} \mathrm{C}$ NMR spectra and are available free of charge at http://jbcs.sbq.org.br, as PDF file.

\section{Acknowledgments}

The authors thank financial support from Brazilian National Agencies CNPq, CAPES and FAPERJ and fellowships researcher provided by CNPq.

\section{References}

1. Leboeuf, M.; Cavé, A.; Bhaumik, P. K.; Mukherjee, B.; Mukherjee, R.; Phytochemistry 1982, 12, 2783.
2. Rupprecht, K. J.; Huai, Y. H.; McLaughlin, J. L.; J. Nat. Prod. 1990, 53, 237.

3. Di Carlo, G.; Madcolo, N.; Izzo, A. A.; Capasso, F.; Life Sci. 1999, 65, 337.

4. Harborne, J. B.; Willians, C. A.; Phytochemistry 2000, 55, 481.

5. Rao, Y. K.; Fang, S. H.; Tzeng, Y. M.; Bioorg. Med. Chem. 2005, 13, 6850 .

6. Grynberg, N. F.; Carvalho, M. G.; Velandia, J. R.; Oliveira, M. O.; Moreira, I. C.; Braz-Filho, R.; Echevarria, A.; Braz. J. Med. Biol. Res. 2002, 35, 819.

7. Gee, J. M.; Johnson, I. T.; Curr. Med. Chem. 2001, 8, 1245.

8. Kumar, S. K.; Hager, E.; Pettit, C.; Gurulingappa, H.; Davidson, N. E.; Khan, S. R.; J. Med. Chem. 2003, 46, 2813.

9. Havsteen, B. H.; Pharmacol. Ther. 2002, 96, 67.

10. Wang J. C.; Annu. Rev. Biochem. 1996, 65, 635.

11. Pott, A; Pott, V. J.; Plantas do Pantanal, Centro de Pesquisa Agropecuária do Pantanal (CPAP): Brasília, 1994.

12. Gonzalez, T. D.; Catálogo de Plantas Medicinales usadas en Paraguay, Comuneros: Asunción, 1992.

13. Dos Santos, P. R. D.; Morais, A. A.; Braz-Filho, R.; J. Braz. Chem. Soc. 2003, 14, 396.

14. Santos, D. Y. A. C.; Salatino, M. L. F.; Phytochemistry 2000, $55,567$.

15. Mossman, T.; J. Immunol. Methods 1983, 65, 55.

16. Agrawal, P. K.; Bansal, M. C. In Carbon 13 NMR of Flavonoids, Studies in Organic Chemistry; Elsevier: Amsterdam, 1989.

17. Vermes, B.; Chari, V. M.; Wagner, H.; Helv. Chim. Acta 1981, 64, 1964.

18. Markham, K. R.; Ternai, B.; Stanley, R.; Geiger, H.; Mabry, T. J.; Tetrahedron 1978, 34, 1389.

19. Lu, Y.; Foo, L. Y.; Food Chem. 1999, 65, 1.

20. Boege, F.; Straub, T.; Kehr, A.; Boesenberg, C.; Christiansen, A. A.; Jakob, F.; Köhrle, J.; J. Biol. Chem. 1996, 271, 2262.

Received: December 15, 2006 Web Release Date: December 12, 2007 


\section{Flavonoids from Annona dioica Leaves and their Effects in Ehrlich Carcinoma Cells, DNA-topoisomerase I and II}

Maria R. G. Vega, ${ }^{a}$ Andressa Esteves-Souza, ${ }^{a}$ Ivo J. C. Vieira, ${ }^{b}$ Leda Mathias, ${ }^{b}$ Raimundo Braz-Filho ${ }^{b}$ and Aurea Echevarria ${ }^{*, a}$

${ }^{a}$ Departamento de Química, Universidade Federal Rural do Rio de Janeiro, 23851-970 Seropédica-RJ, Brazil

${ }^{b}$ Laboratório de Ciências Químicas, Centro de Ciência e Tecnologia, Universidade Estadual do Norte Fluminense, 28013-602 Campos dos Goytacazes-RJ, Brazil

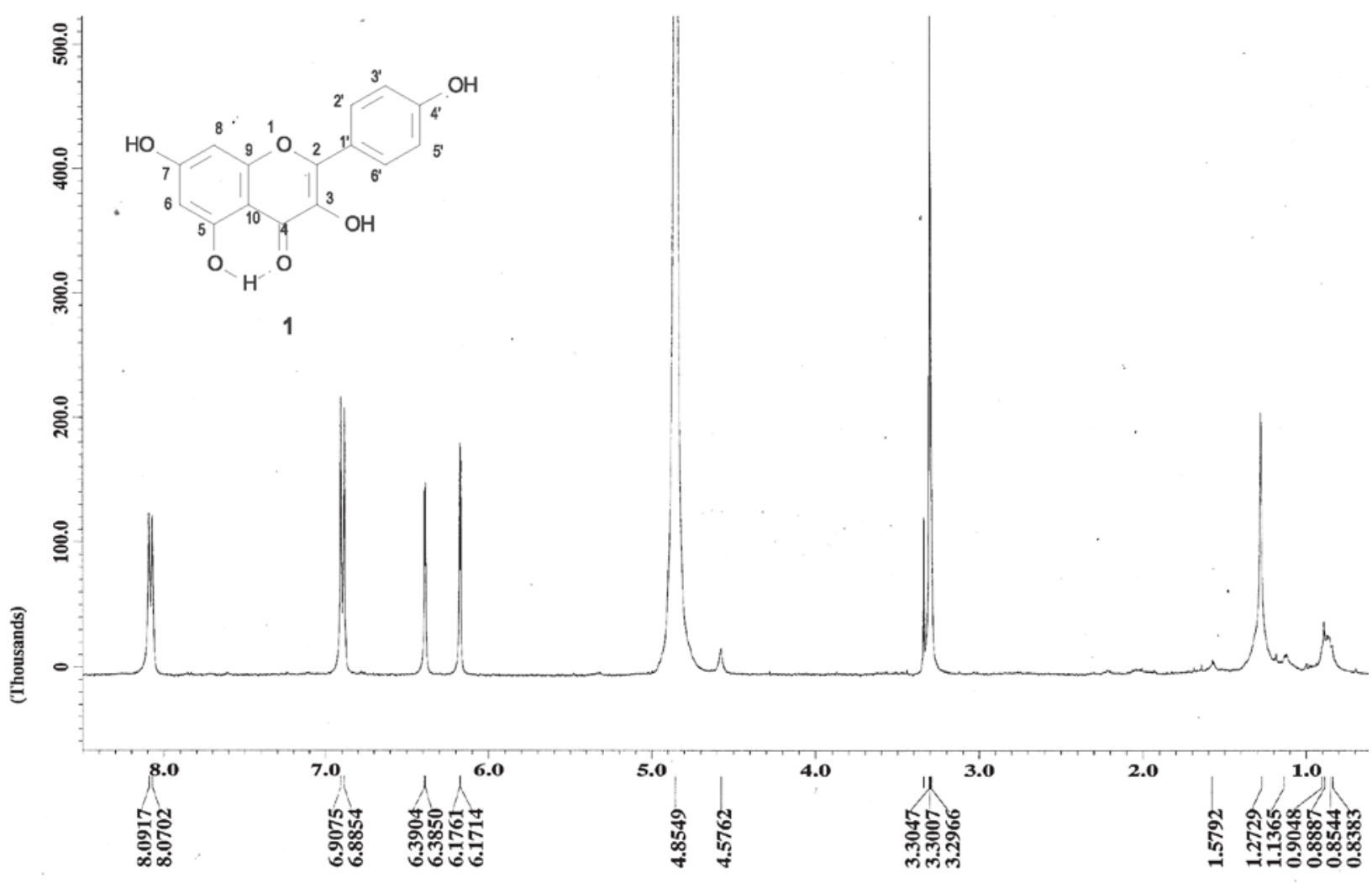

X morte nor Mrillion - $1 \mathrm{H}$

Figure S1. ${ }^{1} \mathrm{H}$ NMR spectrum of flavonoid $1\left(400 \mathrm{MHz}, \mathrm{CD}_{3} \mathrm{OD}\right)$.

*e-mail: echevarr@ufrrj.br 


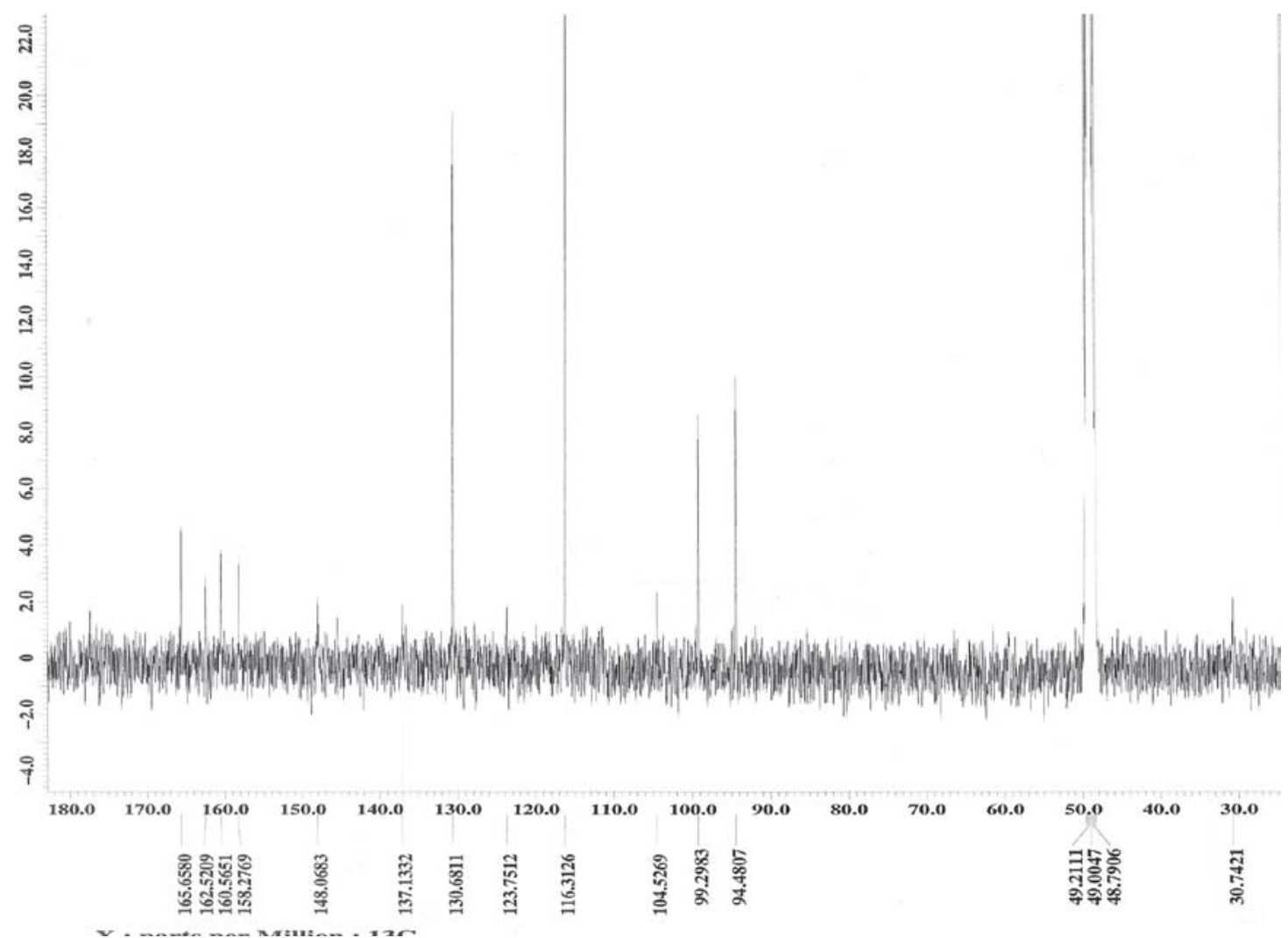

Figure S2. ${ }^{13} \mathrm{C}$ NMR spectrum of flavonoid $\mathbf{1}\left(100 \mathrm{MHz}, \mathrm{CD}_{3} \mathrm{OD}\right)$.

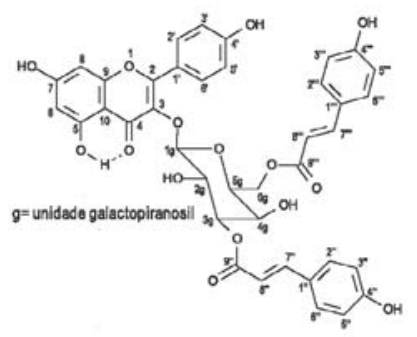

2

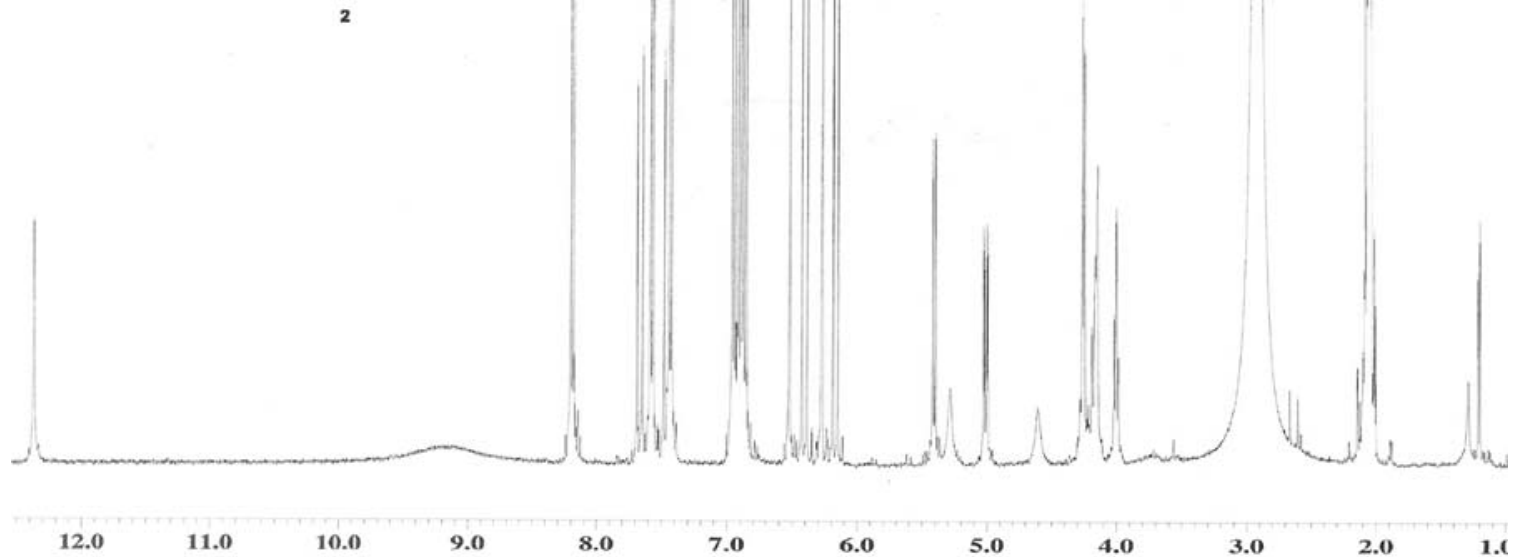

Figure S3. ${ }^{1} \mathrm{H}$ NMR spectrum of flavonoid $2\left(400 \mathrm{MHz}\right.$, acetone- $\left.\mathrm{D}_{6}\right)$. 


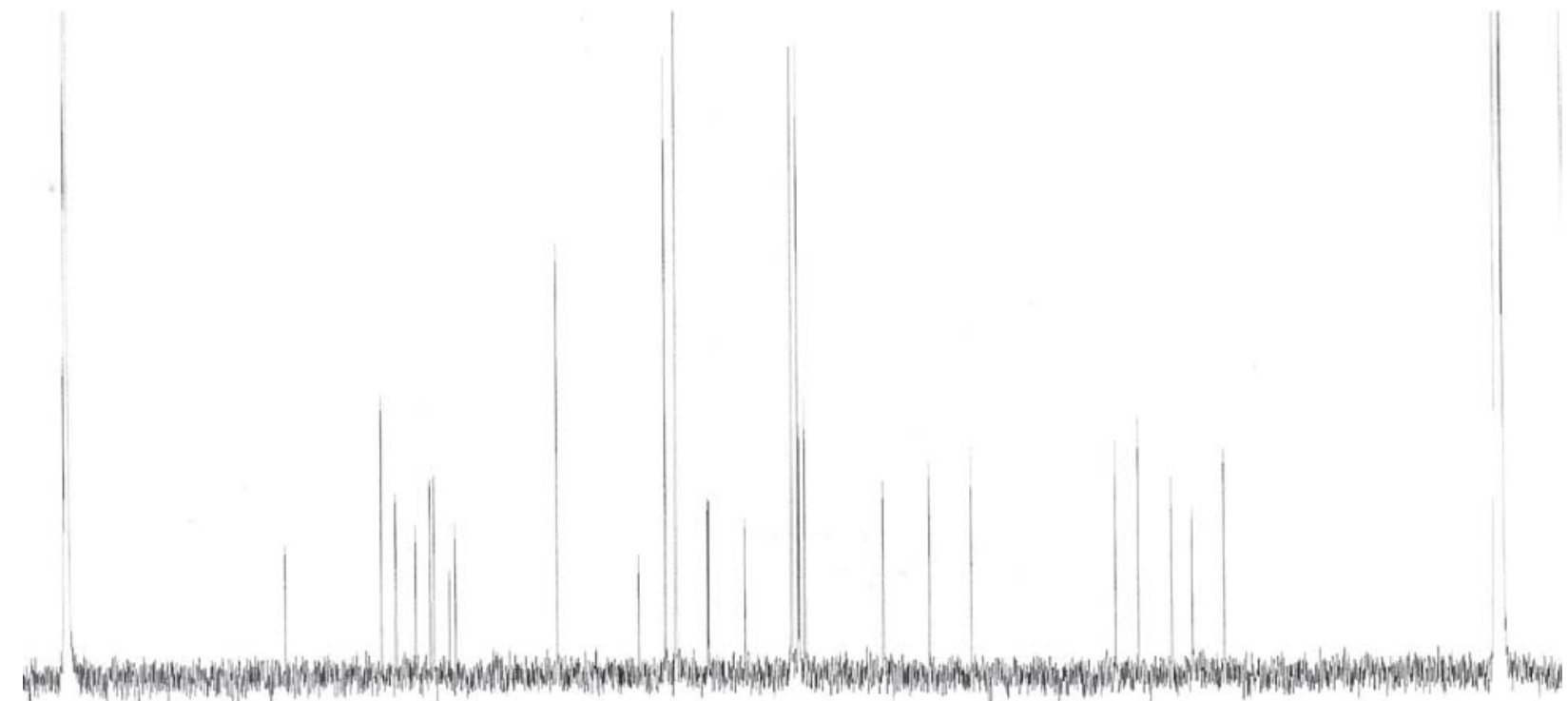

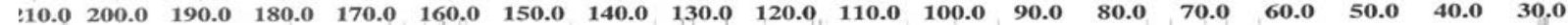

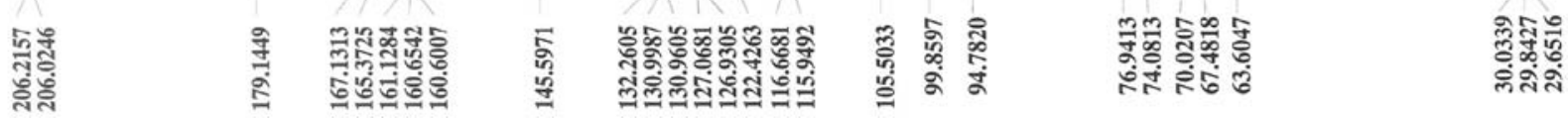

Figure S4. ${ }^{13} \mathrm{C}$ NMR spectrum of flavonoid $2\left(100 \mathrm{MHz}\right.$, acetone-- $\left.\mathrm{D}_{6}\right)$. 


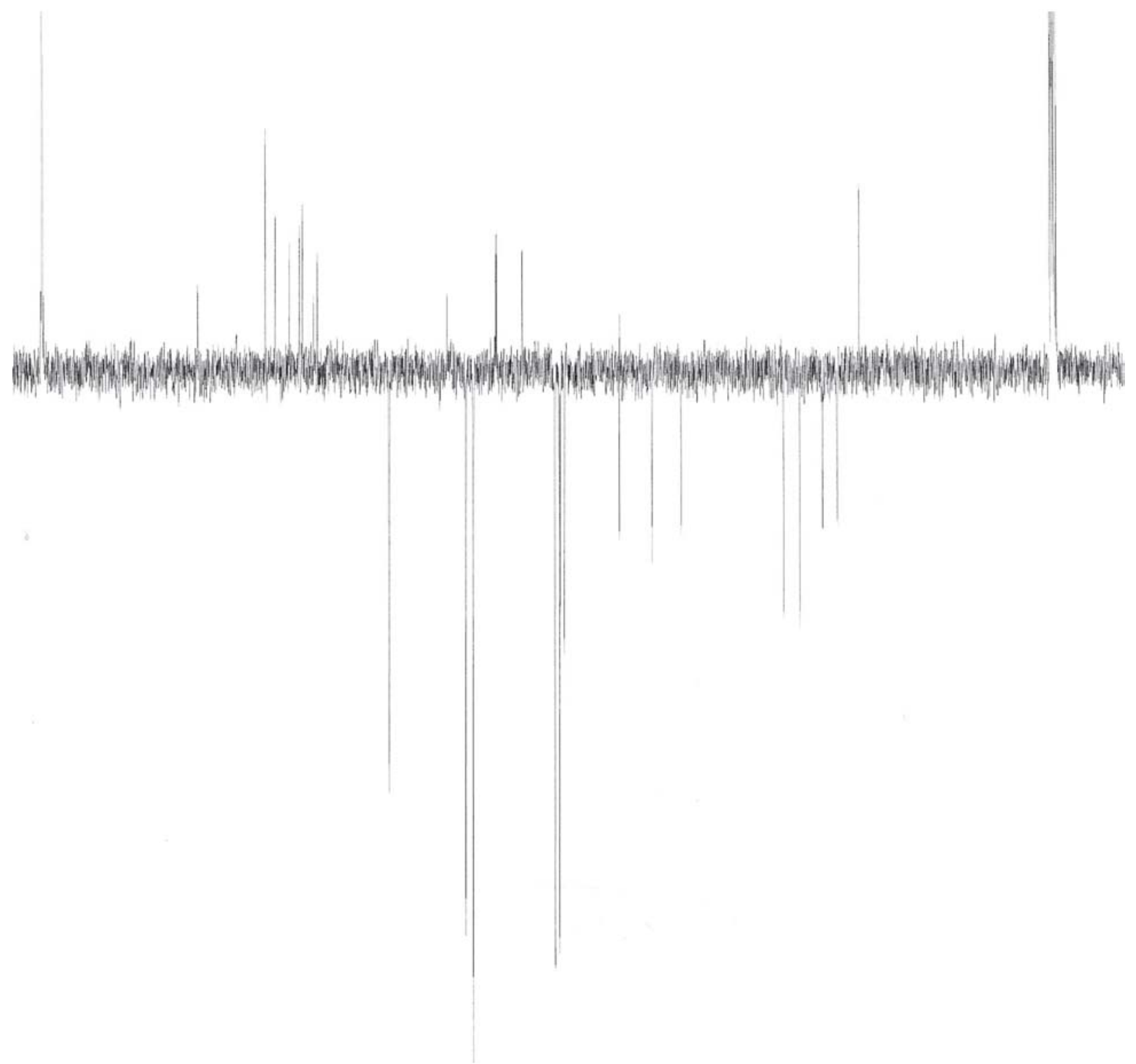

$\begin{array}{llllllllllllllllllll}10.0 & 200.0 & 190.0 & 180.0 & 170.0 & 160.0 & 150.0 & 140.0 & 130.0 & 120.0 & 110.0 & 100.0 & 90.0 & 80.0 & 70.0 & 60.0 & 50.0 & 40.0 & 30.0 & 20.1\end{array}$

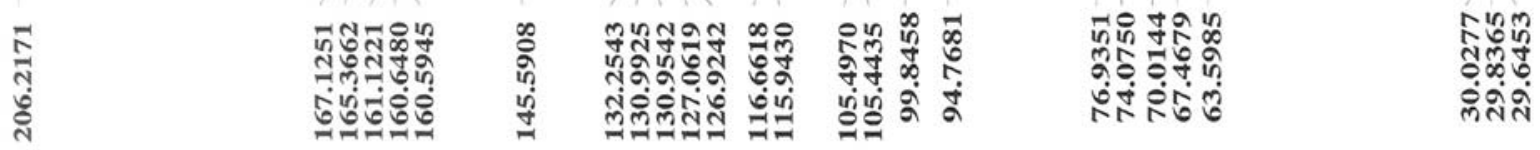

Figure S5. ${ }^{13} \mathrm{C}$ NMR - APT of flavonoid $2\left(100 \mathrm{MHz}\right.$, acetone- $\left.\mathrm{D}_{6}\right)$. 


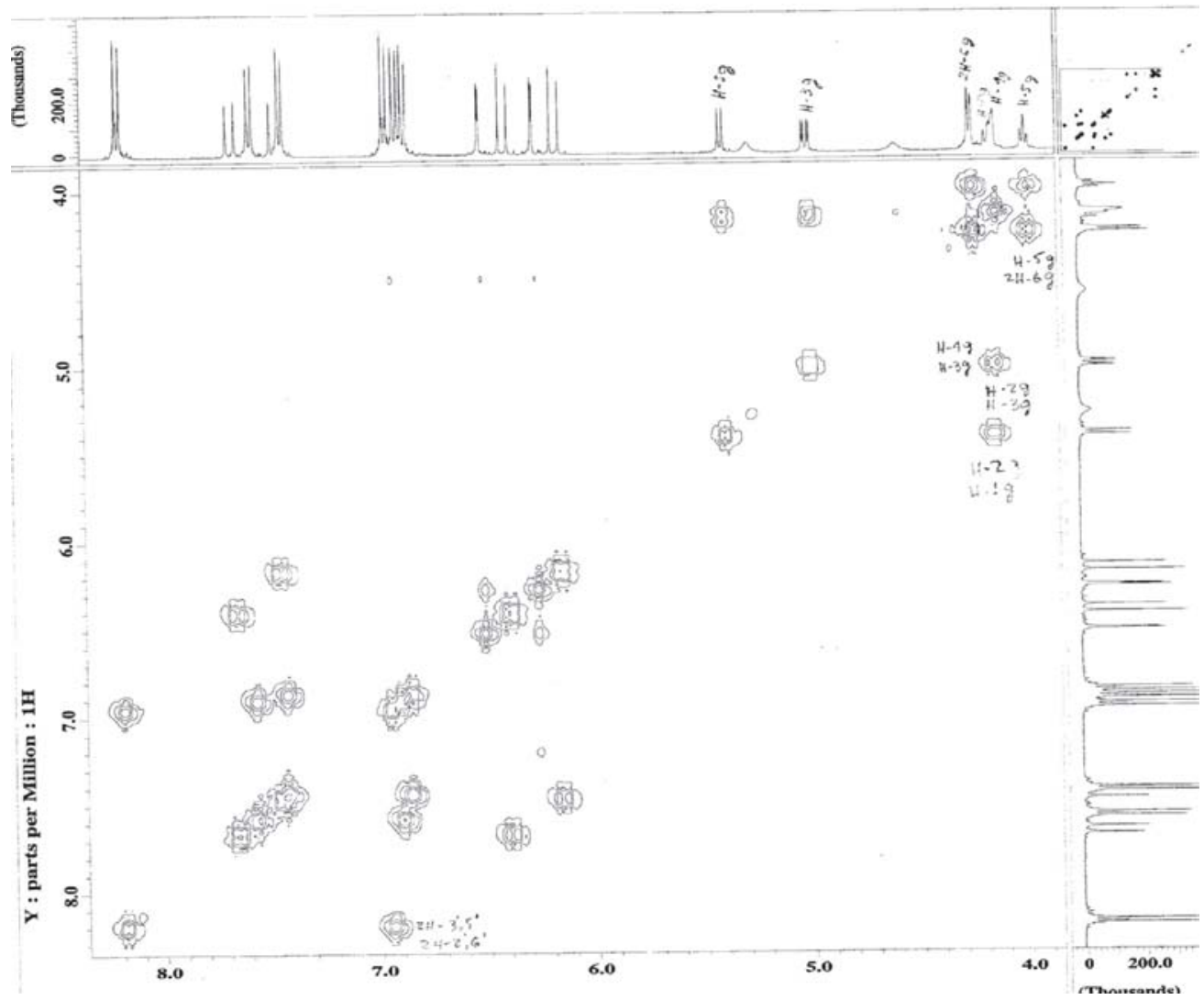

Figure S6. NMR ${ }^{1} \mathrm{H}-{ }^{1} \mathrm{H}-\mathrm{COSY}$ spectrum of flavonoid 2.
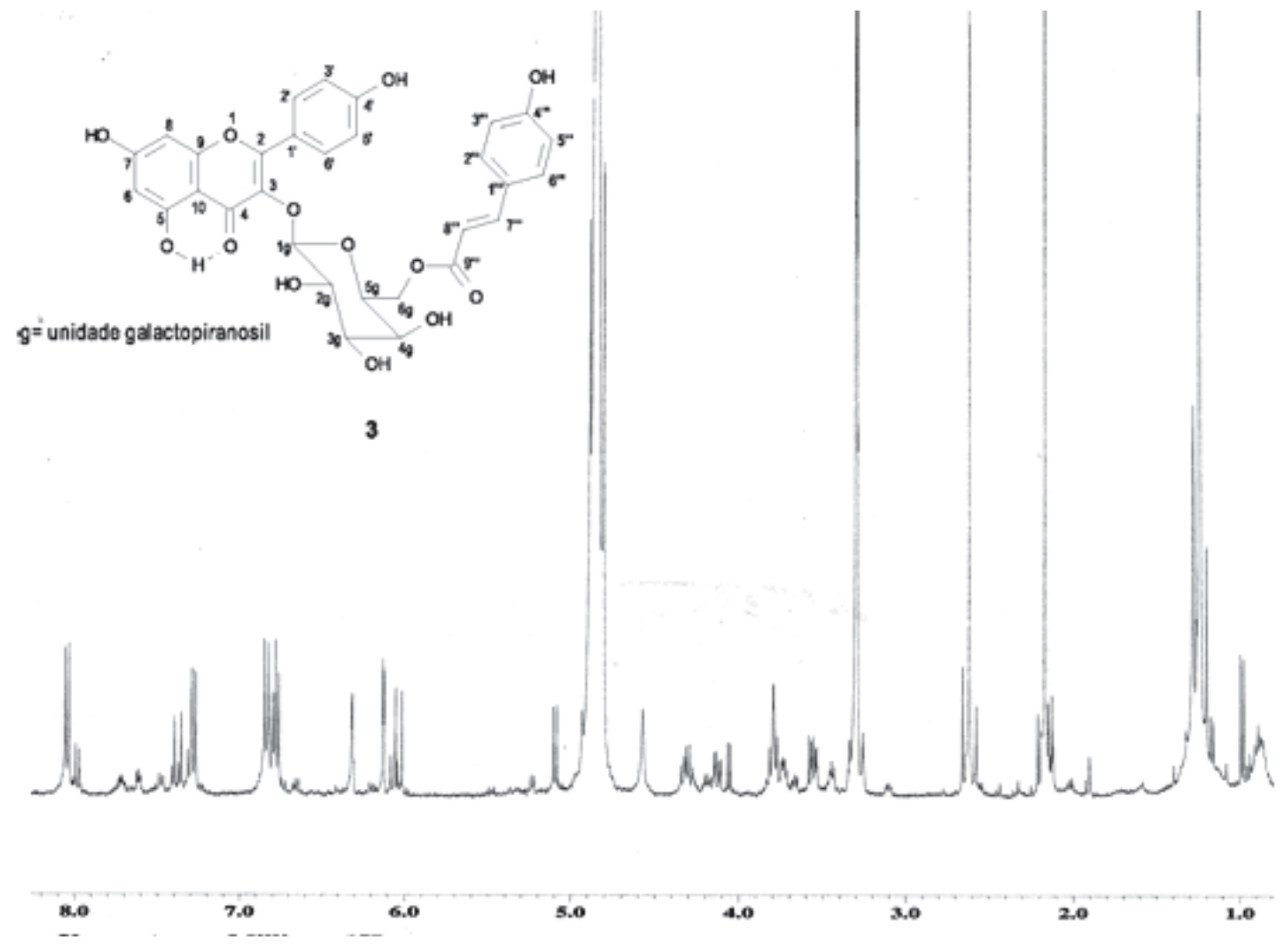

Figure S7. ${ }^{1} \mathrm{H}$ NMR spectrum of flavonoid $3\left(400 \mathrm{MHz}, \mathrm{CD}_{3} \mathrm{OD}\right)$. 


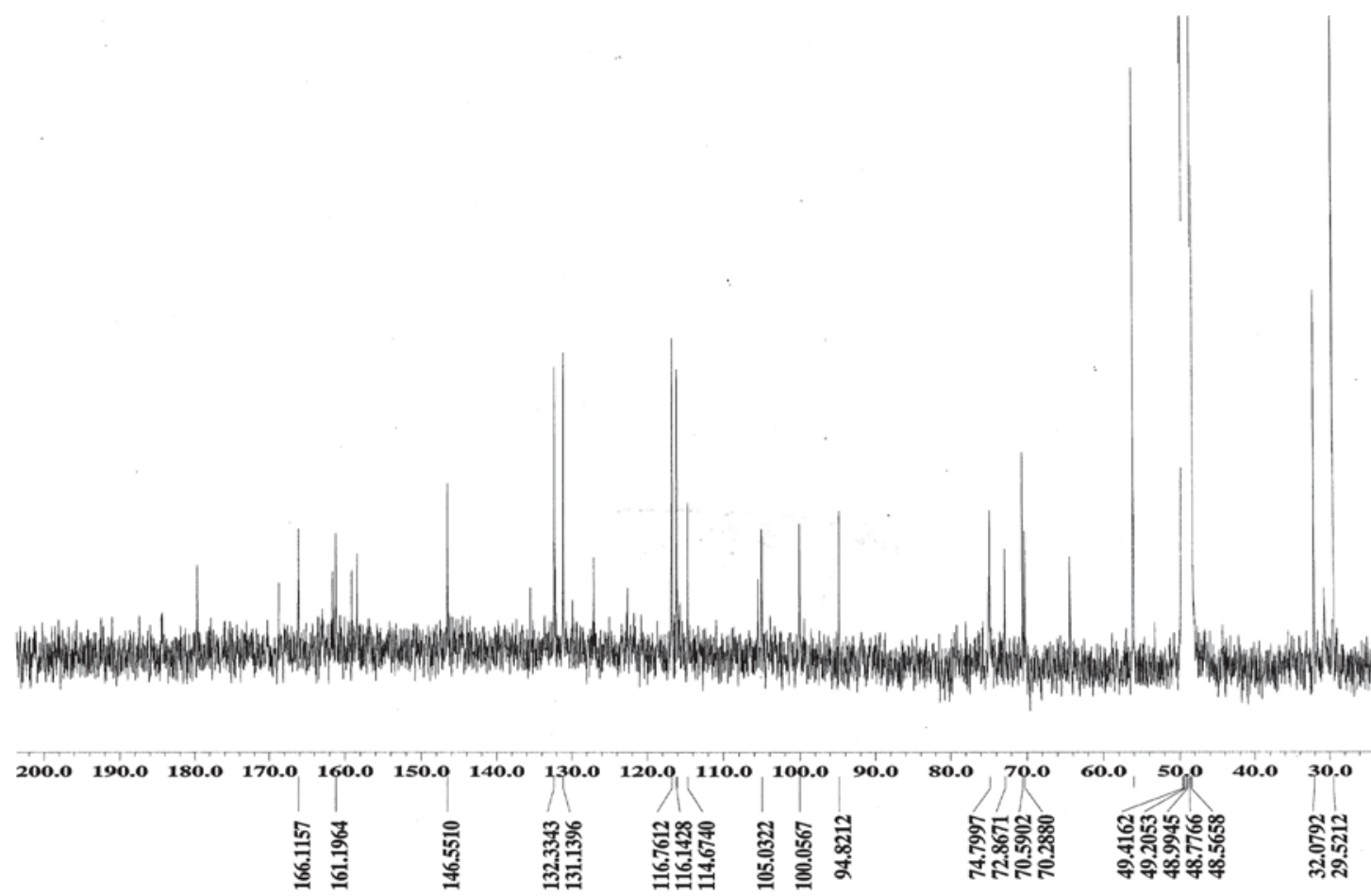

Figure S8. ${ }^{13} \mathrm{C}$ NMR spectrum of flavonoid 3 (100 MHz, $\left.\mathrm{CD}_{3} \mathrm{OD}\right)$.
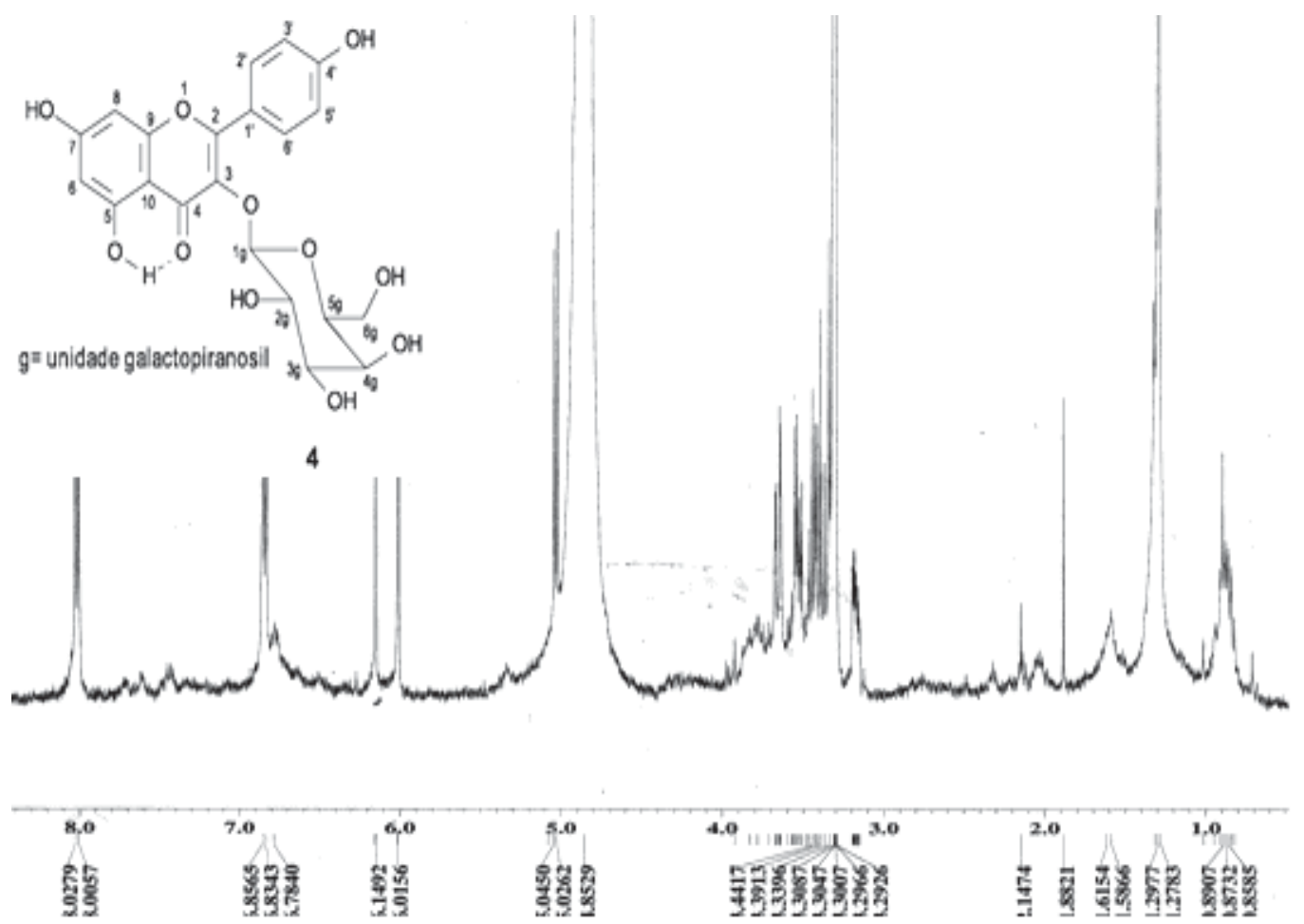

Figure S9. NMR ${ }^{1} \mathrm{H}$ spectrum of flavonoid 4 (400 MHz, $\left.\mathrm{CD}_{3} \mathrm{OD}\right)$. 


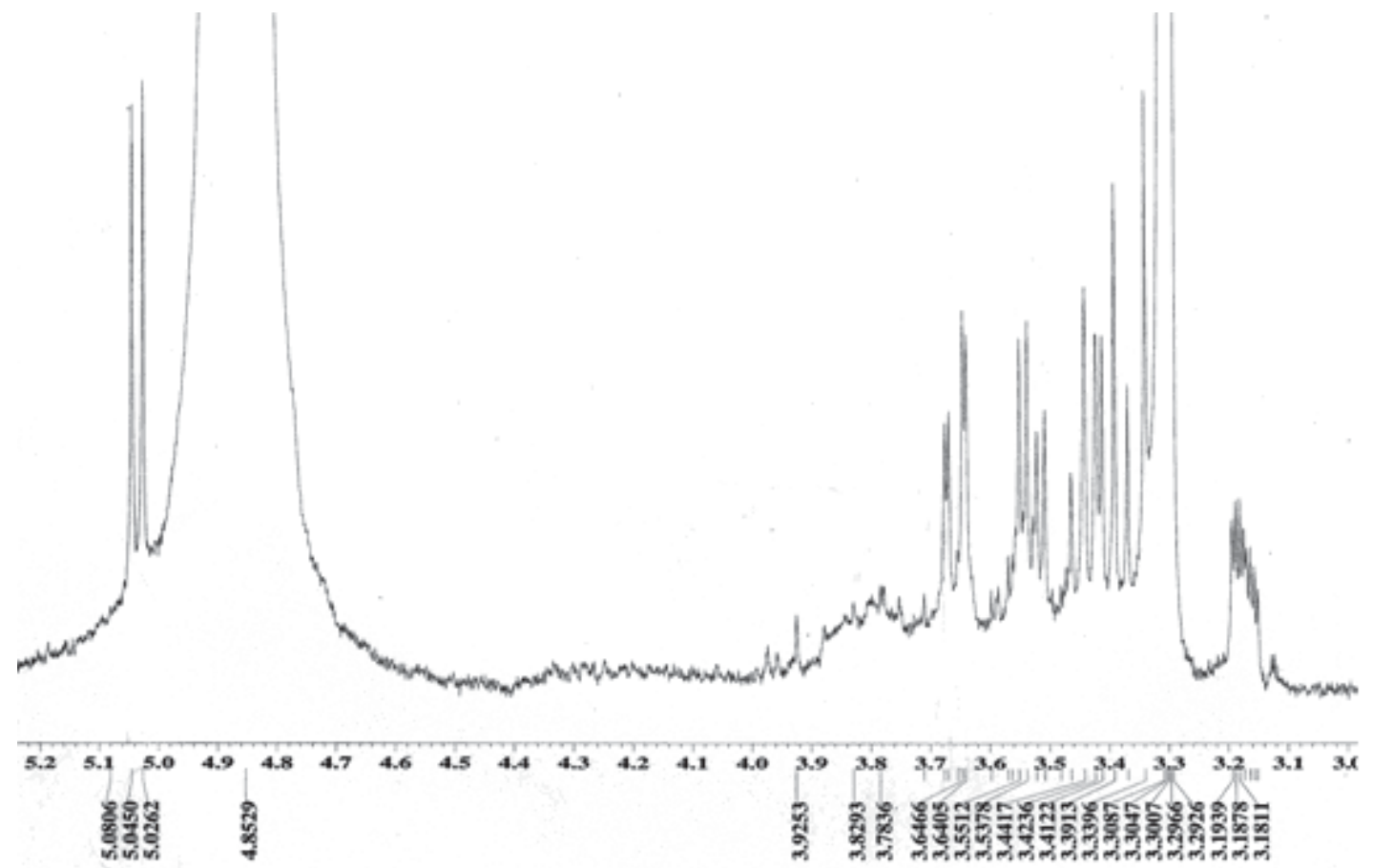

Figure S10. ${ }^{1} \mathrm{H}$ NMR spectrum expansion of flavonoid 4 de $\left(400 \mathrm{MHz}, \mathrm{CD}_{3} \mathrm{OD}\right)$.
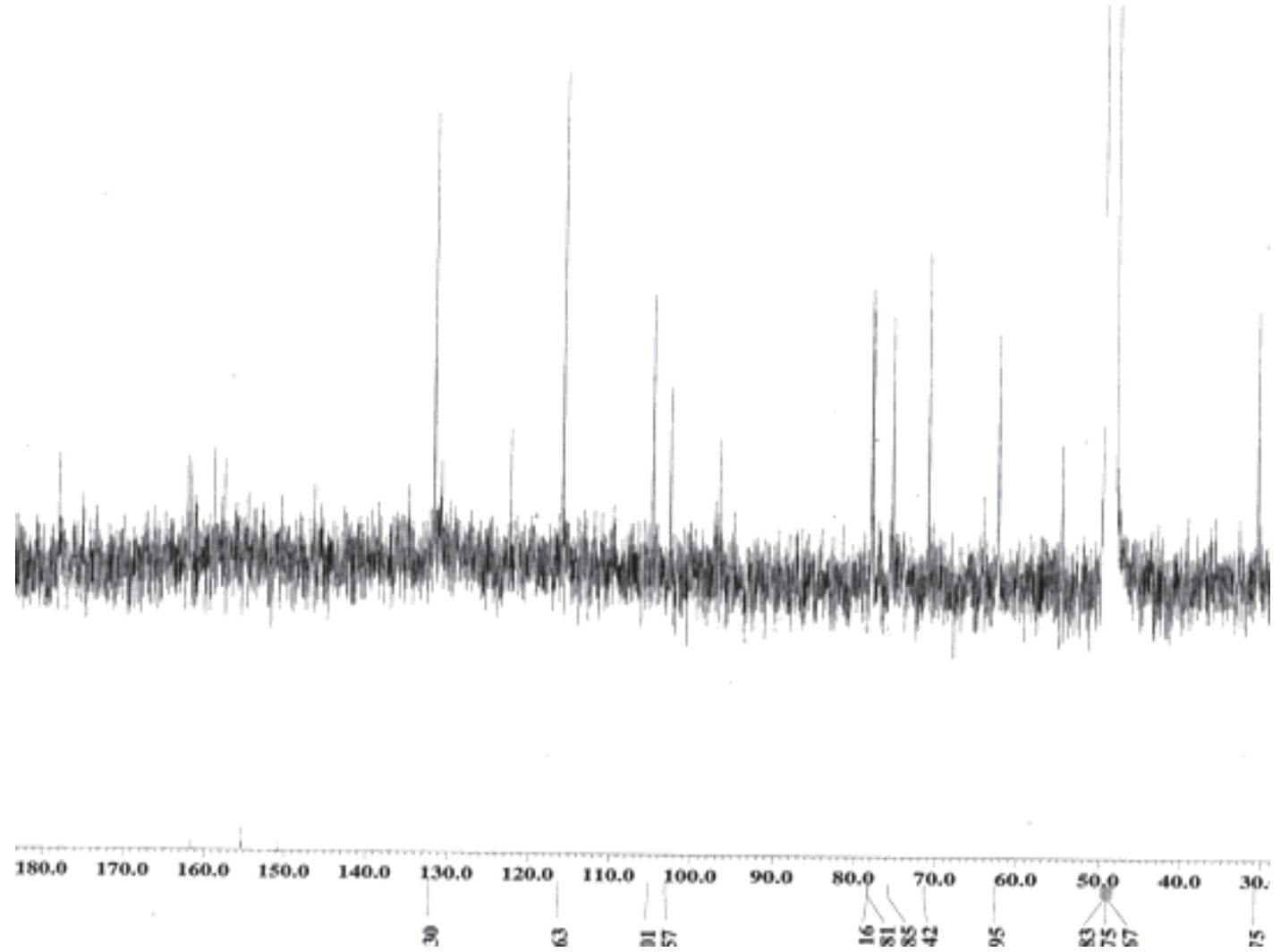

Figure S11. ${ }^{13} \mathrm{C}$ NMR spectrum of flavonoid 4 (100 MHz, $\left.\mathrm{CD}_{3} \mathrm{OD}\right)$. 


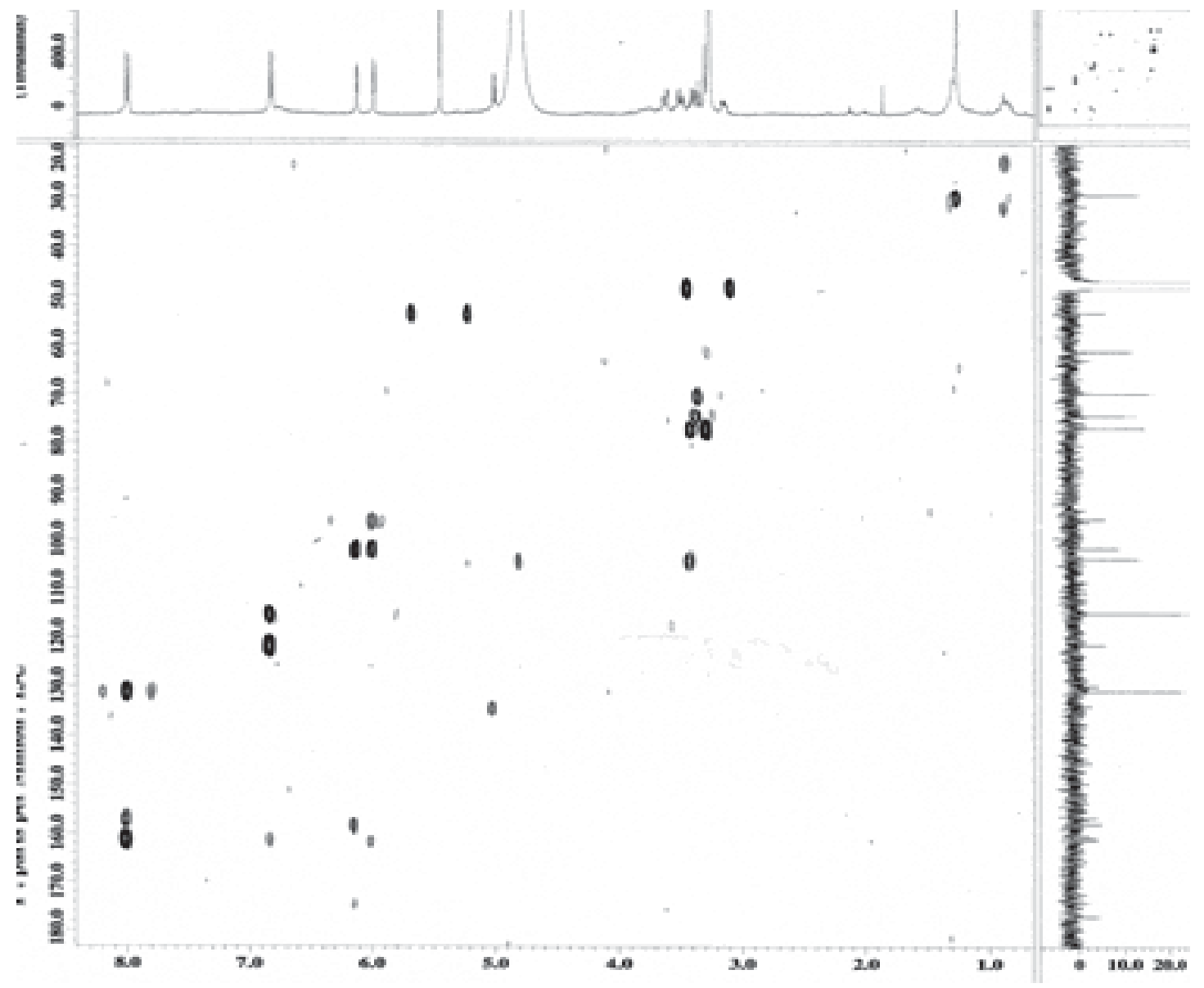

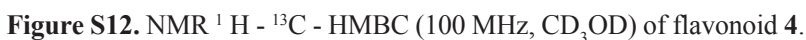

